\begin{tabular}{|c|c|}
\hline Title & Direct measurements of DMS flux from A ntarctic fast sea ice to the atmosphere by a chamber technique \\
\hline Author(s) & Nomura, Daiki; Koga, Seizi; Kasamatsu, Nobue; Shinagawa, Hideo; Simizu, Dai suke; Wada, Makoto; Fukuchi, Mitsuo \\
\hline Citation & $\begin{array}{l}\text { Journal of Geophysical Research : Oceans, 117(C4), C04011 } \\
\text { https://doi.org/10.1029/2010JC006755 }\end{array}$ \\
\hline Issue Date & 2012-04-07 \\
\hline Doc URL & http:/hdl.handle.net/2115/70582 \\
\hline Rights & (c) 2012 A merican Geophysical Union \\
\hline Type & article \\
\hline File Information & Nomura_et_al-2012-Journal_of_Geophysical_Research_Oceans.pdf \\
\hline
\end{tabular}

Instructions for use 


\title{
Direct measurements of DMS flux from Antarctic fast sea ice to the atmosphere by a chamber technique
}

\author{
Daiki Nomura, ${ }^{1,2}$ Seizi Koga,${ }^{3}$ Nobue Kasamatsu, ${ }^{1,4}$ Hideo Shinagawa, ${ }^{5}$ Daisuke Simizu, ${ }^{6}$ \\ Makoto Wada, ${ }^{1}$ and Mitsuo Fukuchi ${ }^{1}$ \\ Received 22 October 2010; revised 1 February 2012; accepted 21 February 2012; published 7 April 2012.
}

[1] We present the first direct measurements of dimethylsulfide (DMS) emissions from Antarctic sea ice to the atmosphere during the seasonal warming period obtained using a chamber technique. Estimated DMS fluxes measured over the snow and superimposed ice (ice formed by the freezing of snow meltwater) were from 0.1 to $0.3 \mu \mathrm{mol} \mathrm{m}^{-2} \mathrm{~d}^{-1}$. The DMS fluxes measured directly over the sea-ice slush layer after removal of the snow and superimposed ice, ranged from 0.1 to $5.3 \mu \mathrm{mol} \mathrm{m}^{-2} \mathrm{~d}^{-1}$, were large compared to those measured over the snow and superimposed ice. The DMS concentrations in slush water ranged from 1.0 to $103.7 \mathrm{nM}$. The DMS fluxes increased with increasing DMS concentrations in slush water. Our results indicate that the potential DMS flux measured over the slush layer occurred originally from the slush layer, and was dependent on the DMS concentrations in slush water. However, snow accumulation and the formation of superimposed ice over the slush layer significantly blocks the diffusion of DMS to the atmosphere, with the result that DMS tends to accumulate in the slush layer although the removal process of DMS by photolysis reaction can modify the DMS flux from the slush layer. Hence, the slush layer has the potential to release the DMS to the atmosphere and ocean when the snow and superimposed ice melts.

Citation: Nomura, D., S. Koga, N. Kasamatsu, H. Shinagawa, D. Simizu, M. Wada, and M. Fukuchi (2012), Direct measurements of DMS flux from Antarctic fast sea ice to the atmosphere by a chamber technique, J. Geophys. Res., 117, C04011, doi:10.1029/2010JC006755.

\section{Introduction}

[2] Sea-to-air emission of dimethylsulfide (DMS) is a major contributor to the global sulfur budget [Liss et al., 1997]. However, ice-covered seas have not been considered in estimations of DMS fluxes because of the assumption that sea ice impedes the release of DMS to the atmosphere. Recent results have indicated that gas exchange of $\mathrm{CO}_{2}$ occurs through sea ice [Semiletov et al., 2004; Delille, 2006; Nomura et al., 2006, 2010a, 2010b; Zemmelink et al., 2006; Loose et al., 2011; Miller et al., 2011; Papakyriakou and Miller, 2011]. However, DMS fluxes from the sea-ice surface

\footnotetext{
${ }^{1}$ National Institute of Polar Research, Tokyo, Japan.

${ }^{2}$ Now at Norwegian Polar Institute, Fram Centre, Tromsø, Norway.

${ }^{3}$ Research Institute for Environment Technology, National Institute of Advanced Industrial Science and Technology, Tsukuba, Japan.

${ }^{4}$ Now at Graduate School of Marine Science and Technology, Tokyo University of Marine Science and Technology, Tokyo, Japan.

${ }^{5}$ Shimoda Marine Research Center, University of Tsukuba, Shizuoka, Japan.

${ }^{6}$ Institute of Low Temperature Science, Hokkaido University, Sapporo, Japan.

Copyright 2012 by the American Geophysical Union. 0148-0227/12/2010JC006755
}

to the atmosphere have rarely been measured [Zemmelink et al., 2008]. Prior to this work, no scientists had carried out direct measurements of DMS fluxes using a chamber technique.

[3] Zemmelink et al. [2008] reported DMS emissions from ice in the Weddell Sea, measured by the relaxed eddy accumulation (REA) method. Results indicating DMS emissions from sea ice to the atmosphere are supported by evidence that sea ice contains a large amount of DMS [Trevena and Jones, 2006; Delille et al., 2007; Zemmelink et al., 2008]. However, the relationship between DMS fluxes measured by REA and DMS concentrations in snow has not yet been determined [Zemmelink et al., 2008], illustrating how difficult it has been to couple DMS concentrations in ice and snow with its flux to the atmosphere. These results suggest a need for detailed in situ measurements of DMS fluxes in conjunction with measurements of DMS concentrations in sea ice to better understand the factors governing DMS fluxes from the sea-ice surface to the atmosphere.

[4] In this study, we used a chamber method to obtain direct measurements of DMS fluxes from sea ice to the atmosphere. This method can be used to directly determine in situ DMS fluxes for various sea surface conditions and to evaluate factors controlling DMS fluxes. This is the first study to use this method for DMS flux measurements from 


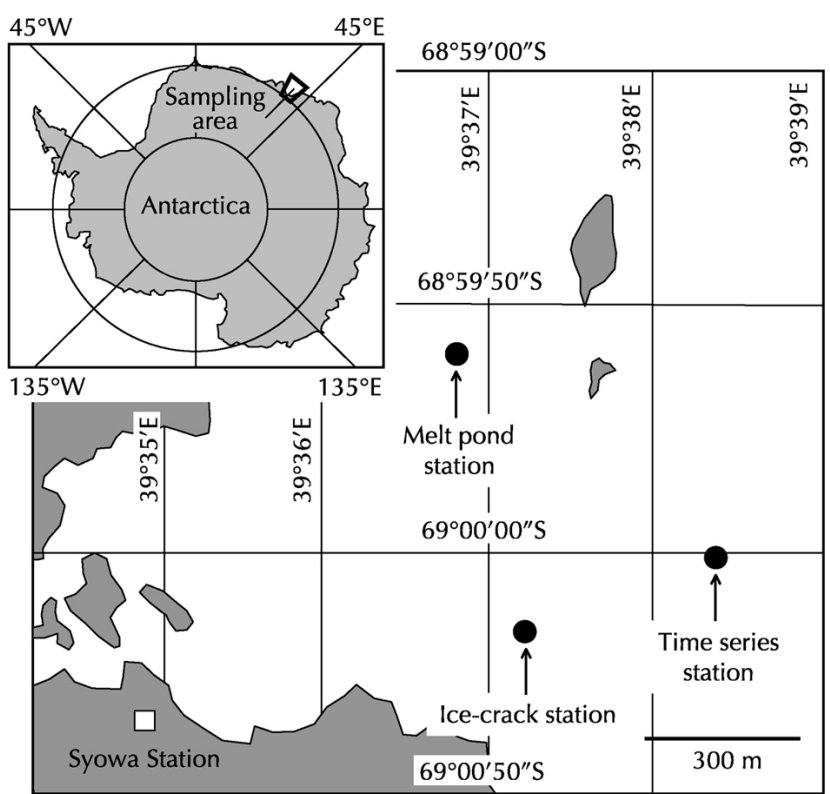

Figure 1. Geographic location of sampling stations on landfast multiyear sea ice in Lützow-Holm Bay, off Syowa Station, Antarctica.

sea ice. This work may help to improve estimates of the sulfur budget and advance our understanding gas exchange processes occurring in the polar oceans.

\section{Materials and Methods}

[5] We performed the sampling over landfast multiyear sea ice in Lützow-Holm Bay, off Syowa Station, Antarctica $\left(68^{\circ} 59^{\prime}-69^{\circ} 01^{\prime} \mathrm{S}, 39^{\circ} 36^{\prime}-39^{\circ} 39^{\prime} \mathrm{E}\right)$ from 12 January to 2 February 2010 (Figure 1) during the 51st Japanese Antarctic Research Expedition (JARE-51). We collected samples from (1) a station on level ice for time series analyses, (2) a station near an ice crack $0.09 \mathrm{~m}$ wide and about $500 \mathrm{~m}$ long, and (3) a melt pond on the landfast ice. We selected these three sites for sampling at this time in order to obtain data for different sea-ice-surface conditions during the icemelting season.

[6] A schematic illustration of the ice structure is shown in Figure 2. At the time series station, sea ice and snow thicknesses were $1.6-2.3 \mathrm{~m}$ and $0.1-0.3 \mathrm{~m}$, respectively (Table 1). Because the sea ice had negative freeboard, a slush layer (gap layer) with a thickness of $0.07-0.19 \mathrm{~m}$ had developed at the snow-sea ice interface. At the bottom of the snow cover, we observed superimposed ice (an ice layer formed by the freezing of snow meltwater) with a thickness of $0.06-0.10 \mathrm{~m}$ (Table 1$)$. At the station near the ice crack, the structure of the ice was almost the same as in the levelice region; ice, snow, and slush layer thicknesses were 3.41, 0.54 , and $0.19 \mathrm{~m}$, respectively. The area of the melt pond was $5-7 \mathrm{~m}^{2}$, and the pond water depth was $0.17-0.20 \mathrm{~m}$. The surface of the melt pond was covered with ice $0.07 \mathrm{~m}$ thick (Table 1).

[7] We determined DMS fluxes from the sea-ice surface to the atmosphere from the change in DMS concentrations in air within an airtight, Teflon-coated chamber $(0.50 \mathrm{~m}$ in diameter and $0.30 \mathrm{~m}$ high with a serrated bottom edge),

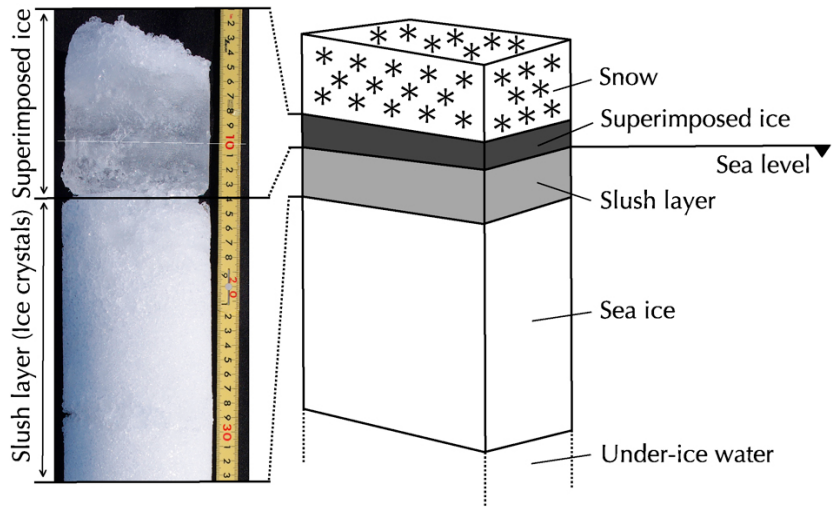

Figure 2. (right) Schematic illustration of the ice structure during the data-collection period. (left) Core stratigraphy is based on a photograph taken at the time series station. Because this photograph was taken of the superimposed ice and slush layer in a core collected by the ice corer, the water drained out of the slush layer as the core was raised above the top of the sea ice. As a result, the slush layer in the photograph is composed mainly of ice crystals.

allowing direct determination of the in situ gas flux from sea ice [Delille, 2006; Nomura et al., 2010a, 2010b].

[8] The chamber, which did not have a fan, was installed over snow at the time series and ice-crack stations. At the melt pond station, the chamber was installed over the pond ice. The chamber was pushed down firmly into the snow at the time series and ice-crack stations and into the ice at the melt pond station to prevent lateral diffusion of gas. Experiments lasted for $40 \mathrm{~min}$. Every $10 \mathrm{~min}$ during an experiment, $400 \mathrm{~mL}$ of air in the chamber was collected using a $50 \mathrm{~mL}$ glass syringe with a three-way valve and then transferred to a $2000 \mathrm{~mL}$ Tedlar bag. Before each sample was collected, the glass syringe was carefully pumped to homogenize the air in the chamber. A $2000 \mathrm{~mL}$ Tedlar bag, which was covered with a Teflon bag (Jensen Inert Products, Florida, USA), was installed within the chamber as a pressure regulator to avoid any effect from pressure changes during the collection of air samples.

[9] After the DMS flux measurement over the snow at the time series and ice-crack stations, snow and superimposed ice were removed with a scoop, and ice crystals in the slush layer were removed with a net. At the melt pond station, the

Table 1. Sampling Date, Stations, and Thickness of Sea Ice, Snow, Superimposed Ice, and the Slush Layer

\begin{tabular}{cccccc}
\hline & & \multicolumn{4}{c}{ Thickness (m) } \\
\cline { 3 - 6 } & & \multicolumn{4}{c}{ Superimposed } \\
Date & Station & Sea Ice & Snow & Ice & Slush Layer \\
\hline 12 Jan 2010 & Time series & 1.55 & 0.23 & 0.09 & 0.13 \\
14 Jan 2010 & Time series & 1.70 & 0.28 & 0.10 & 0.13 \\
18 Jan 2010 & Time series & 1.74 & 0.12 & 0.10 & 0.07 \\
19 Jan 2010 & Time series & 1.92 & 0.09 & 0.06 & 0.11 \\
27 Jan 2010 & Ice crack & 3.41 & 0.54 & ND $^{\mathrm{a}}$ & 0.19 \\
30 Jan 2010 & Melt pond & ND $^{\mathrm{a}}$ & 0 & $0.07^{\mathrm{b}}$ & $0.17-0.20^{\mathrm{c}}$ \\
2 Feb 2010 & Time series & 2.33 & 0.06 & 0.08 & 0.08 \\
\hline
\end{tabular}

${ }^{\mathrm{a} N D}$ means no data.

${ }^{\mathrm{b}}$ Thickness of pond ice.

${ }^{\mathrm{c}}$ Depth of melt pond. 


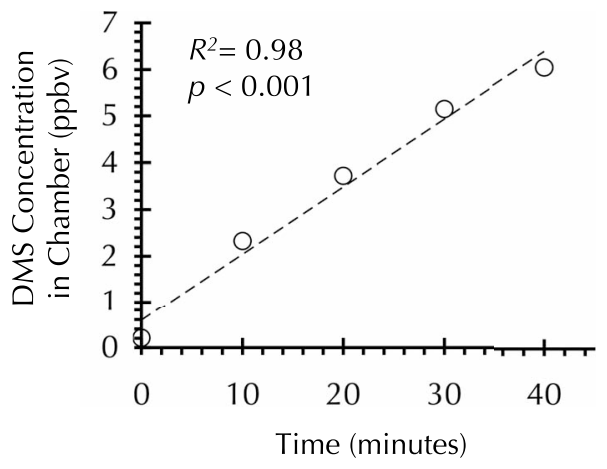

Figure 3. Temporal variations in the DMS concentration in the chamber over the slush layer at the time series station on 12 January 2010 . The regression line was obtained using all of the points plotted.

pond ice was cut with a saw, and ice in the pond water was removed with a net. The chamber was then installed over the slush layer at the time series and ice-crack stations, and over the pond water at the melt pond station. The chamber was pushed down firmly into the slush layer at the time series and ice-crack stations and into the melt pond at the melt pond station to prevent lateral diffusion of gas. Air in the chamber was collected in the same manner as chamber air collected over snow.

[10] After collection, air samples were quickly transported in a dark container to a laboratory onboard the Japan Maritime Self-Defense Force icebreaker Shirase, which was moored near our sampling region. The DMS concentrations were measured with a proton transfer reaction-mass spectrometer (IONICON High-Sensitivity PTR-MS, IONICON Analytik $\mathrm{GmbH}$, Innsbruck, Austria) within $5 \mathrm{~h}$ of sample collection. The PTR-MS can perform continuous analyses of volatile organic compounds with high sensitivity (at the ppt level). Gas standards for PTR-MS calibration were produced by a gas calibration unit (Ionimed Analytik GmbH, Innsbruck, Austria), which contained 1 ppmv DMS within an internal SilcoCan canister (Apel-Riemer Environmental, Inc., Broomfield, CO, USA). Changes in the DMS concentration in the air in a Tedlar bag before and after a storage time of $5 \mathrm{~h}$ were small $(<0.20 \mathrm{ppbv})$, indicating that a Tedlar bag is appropriate for use as a sampling bag for DMS measurements.

[11] The DMS flux measured over the slush layer at the time series station on 12 January 2010 is shown in Figure 3. The DMS concentration in the chamber increased with time, indicating that DMS was emitted from the slush layer to the atmosphere. We calculated the DMS fluxes using the following equation:

$$
F=(V / R T S)(\Delta C / \Delta t),
$$

where $F$ is the DMS flux $\left(\mu \mathrm{mol} \mathrm{m}{ }^{-2} \mathrm{~d}^{-1}\right), V$ is the chamber headspace volume $\left(\mathrm{m}^{3}\right)$ adjusted for the volume occupied by the snow and slush, $R$ is the gas constant $\left(\mathrm{atm} \mathrm{m} \mathrm{mol}^{-1}\right.$ $\left.\mathrm{K}^{-1}\right), T$ is the air temperature $(\mathrm{K})$ within the chamber measured by a temperature data logger (RTR 52, T \& D Corp., Nagano, Japan), $S$ is the area $\left(\mathrm{m}^{2}\right)$ of the snow or slush within the chamber, and $\Delta C / \Delta t$ is the time rate (ppbv d ${ }^{-1}$ ) of change in the DMS concentration in the air within the chamber. Only experimental results yielding high correlation coefficients $\left(R^{2} \geq 0.8\right)$ were used for DMS flux calculations. The precision of duplicate measurements of the DMS flux from the sea ice to the atmosphere, examined using the same time frame $\left(1-2 \mathrm{~h}\right.$ ) and area (within $2 \mathrm{~m}^{2}$ ), was within $\pm 0.3 \mu \mathrm{mol} \mathrm{m} \mathrm{m}^{-2} \mathrm{~d}^{-1}$. The uncertainty of the DMS flux measurements, indicated by the standard error of the regression line between the DMS concentration and elapsed time, was $\pm 17 \%$. In this paper, we express the DMS flux measured over the snow and superimposed ice as $\mathrm{F}_{\mathrm{s} / \mathrm{s}}$, and the flux measured directly over the slush layer (after removal of the snow and superimposed ice) as $\mathrm{F}_{\text {slush }}$.

[12] Soon after the collection of the samples for the DMS flux measurement, water samples were collected from the slush layer and the melt pond with a diaphragm pump (EWP-01, AS ONE Corporation, Osaka, Japan) via an attached Teflon tube. To avoid additional production of DMS from phytoplankton cells during the equilibration period, the water samples collected from the slush layer and the melt pond were filtered through a glass column filter (KF-18, AS ONE Corporation, Osaka, Japan) installed at the inlet of the Teflon tube. Then, each water sample was quickly transferred to an equilibrator consisting of a glass column in which the volume and height of water were $1000 \mathrm{~mL}$ and $15 \mathrm{~cm}$, respectively, and which had a bubbler head at the bottom of the column. The equilibrator was connected to an air pump and a $2000 \mathrm{~mL}$ Tedlar bag containing $200 \mathrm{~mL}$ of air. A Tedlar bag was also used as a pressure regulator in a closed loop to prevent any effects of pressure changes on the measured DMS concentration during the equilibration. Air was fully circulated through a closed loop at a flow rate of $1 \mathrm{~L}$ minute ${ }^{-1}$ for $3 \mathrm{~min}$ to equilibrate gases in the water and air. The DMS concentration in the Tedlar bag was measured in the same manner as air collected from the chamber. Because equilibration of the DMS in the water and air was established within a closed system, the DMS concentration measured in the Tedlar bag was corrected considering the volumes of the water $(1000 \mathrm{~mL})$ and gas phase $(200 \mathrm{~mL})$. In addition, the DMS concentration dissolved in the water, which is a function of water temperature and salinity, was calculated using Henry's law and the parameterization of Dacey et al. [1984]. The precision of duplicate analyses of DMS concentrations in slush water using the equilibrator was within $\pm 5.0 \mathrm{nM}$. Because slush water samples were collected from two spots within a $2 \mathrm{~m}^{2}$ area on each sampling day, the precision of duplicate measurements $( \pm 5.0 \mathrm{nM})$ reflects both the spatial variability of the samples and the experimental equilibration error. For measuring DMS concentration in surface seawater, Kameyama et al. [2009] also used a similar type of equilibrator in which the volume and height of water were $10 \mathrm{~L}$ and $60 \mathrm{~cm}$ respectively. In their method, DMS reached equilibrium (equilibrium efficiency of $100 \%$ ) within 1 min interval at airflow of 0.1-0.5 L minute ${ }^{-1}$ for artificial DMS standard seawater. In our study, due to equipment limitations for preparing the DMS standard seawater, no calibrations were carried out to examine the equilibrium efficiency of our equilibrator. However, because air was fully circulated within the equilibrator during $3 \mathrm{~min}$ at higher flow rate (1 L minute ${ }^{-1}$ ) compared to equilibration time (about $1 \mathrm{~min}$ ), the DMS equilibration would be established in our analytical method.

[13] Under-ice water was collected with a Teflon water sampler (GL Science Inc., Tokyo, Japan) $1 \mathrm{~m}$ below the 
Table 2. Salinity, Chlorophyll $a$, DMS Concentrations for Slush and Under-Ice Water, and DMS Flux

\begin{tabular}{|c|c|c|c|c|c|c|c|c|c|}
\hline \multirow[b]{2}{*}{ Date } & \multirow[b]{2}{*}{ Station } & \multicolumn{2}{|c|}{ Salinity } & \multicolumn{2}{|c|}{$\begin{array}{l}\text { Chlorophyll } a \\
\quad\left(\mu \mathrm{g} \mathrm{L}^{-1}\right)\end{array}$} & \multicolumn{2}{|c|}{$\begin{array}{l}\text { DMS Concentration } \\
(\mathrm{nM})\end{array}$} & \multicolumn{2}{|c|}{$\begin{array}{c}\text { DMS Flux } \\
\left(\mu \mathrm{mol} \mathrm{m}^{-2} \mathrm{~d}^{-1}\right)\end{array}$} \\
\hline & & Slush & $\begin{array}{l}\text { Under-Ice } \\
\text { Water }\end{array}$ & Slush & $\begin{array}{l}\text { Under-Ice } \\
\text { Water }\end{array}$ & Slush & $\begin{array}{l}\text { Under-Ice } \\
\text { Water }\end{array}$ & $\mathrm{F}_{\mathrm{s} / \mathrm{s}}$ & $\mathrm{F}_{\text {slush }}$ \\
\hline 12 Jan 2010 & Time series & $5.4-6.2$ & 33.2 & $0.06-0.09$ & 0.05 & $17.2-19.9$ & 4.4 & 0.10 & $0.40-1.08$ \\
\hline 14 Jan 2010 & Time series & $5.7-6.8$ & 33.7 & $0.75-1.11$ & 0.09 & $8.1-16.3$ & 2.9 & 0.05 & $0.76-1.03$ \\
\hline 18 Jan 2010 & Time series & $3.0-3.1$ & 32.9 & $0.73-1.12$ & 0.28 & $4.2-6.0$ & 6.5 & 0.11 & $0.35-0.41$ \\
\hline 19 Jan 2010 & Time series & $2.4-3.3$ & 32.3 & $0.28-0.78$ & 0.22 & $4.2-4.7$ & 7.0 & 0.10 & $0.28-0.34$ \\
\hline 27 Jan 2010 & Ice crack & $0.7-9.4$ & 29.7 & $0.17-2.69$ & 0.10 & $4.9-103.7$ & 6.2 & 0.26 & $0.12-5.30$ \\
\hline 30 Jan 2010 & Melt pond & $0.1-0.1^{\mathrm{a}}$ & 33.0 & $0.02-0.02^{\mathrm{a}}$ & 0.19 & $1.1-3.7^{\mathrm{a}}$ & 11.2 & 0.08 & $0.08-0.11^{\mathrm{b}}$ \\
\hline 2 Feb 2010 & Time series & $0.8-0.9$ & 31.1 & $0.02-0.03$ & 1.04 & $1.0-1.3$ & 9.5 & 0.09 & 0.11 \\
\hline
\end{tabular}

${ }^{\mathrm{a}}$ Melt pond water.

${ }^{\mathrm{b}}$ Flux measured over the melt pond water.

bottom of the sea ice, and the DMS concentration was measured in the same manner as for slush.

[14] Slush, melt pond water, and under-ice water were also analyzed for salinity and chlorophyll $a$ concentrations. Salinities were measured with a salinity analyzer (SAT-210, Toa Electronics Ltd., Tokyo, Japan). For chlorophyll $a$ measurements, samples were filtered through $25 \mathrm{~mm}$ Whatman GF/F filters. Pigments on the filters were extracted in dimethylformamide [Suzuki and Ishimaru, 1990] for $24 \mathrm{~h}$ at approximately $-80^{\circ} \mathrm{C}$. Concentrations of pigments were determined using a fluorometer (Model 10AU, Turner Designs, Inc., USA), following methods described by Parsons et al. [1984].

[15] Samples of snow and superimposed ice were collected using a clean polycarbonate shovel and an ice corer (Geo Tecs Co., Ltd., Chiba, Japan), similar in design to a Kovacs corer and with an internal diameter of $9.0 \mathrm{~cm}$, at the time series station on 11, 19, and 29 January. Each sample was placed into double-polyethylene zip-lock bags and a black polyethylene bag to maintain a low temperature to prevent the algae from experiencing a temperature shock during the melting in the dark at room temperature. During the melting period, the melting process was carefully observed, and as soon as the sample finished melting, the sample water was filtered for chlorophyll $a$ measurement. It took 1-2 days for the whole sample to melt. Therefore, the temperature shock experienced during ice melting would be small for algae [Mikkelsen and Witkowski, 2010]. In addition, in this study, we did not add filtered seawater or artificial seawater to the ice samples because osmotic stress, which can cause cells to lyse, is considered to be small using our approach [Mikkelsen and Witkowski, 2010]. Samples for measurements of salinity and chlorophyll $a$ concentrations were treated in the same manner as the slush and under-ice water samples.

\section{Results and Discussion}

\subsection{DMS Concentrations in Slush, Melt Pond Water, and Under-Ice Water}

[16] The DMS concentrations in slush water ranged from 1.0 to $103.7 \mathrm{nM}$ (Table 2). These values are consistent with the results previously reported by Zemmelink et al. [2008], who showed that DMS concentrations in slush water ranged from $<1$ to $92 \mathrm{nM}$ in multiyear ice in the Weddell Sea, and that high DMS concentrations occurred in biologically productive slush.
[17] At the time series station on level ice, mean DMS concentration in slush water decreased with time from $18.6 \mathrm{nM}$ on 12 January to $1.1 \mathrm{nM}$ on 2 February (Figure $4 \mathrm{a}$ and Table 2). Mean salinity of slush water also decreased from 5.8 on 12 January to 0.8 on 2 February. In addition, snow thickness decreased from $0.23 \mathrm{~m}$ on 12 January to $0.06 \mathrm{~m}$ on 2 February (Table 1). Chlorophyll $a$ concentrations in the slush water varied from 0.0 to $1.1 \mu \mathrm{g} \mathrm{L}^{-1}$ (Table 2). The temporal variations in chlorophyll $a$ concentrations in the slush water showed no relationship with the variations in DMS concentrations or salinity (Figure $4 b$ ).

[18] During the observation period, air temperature was frequently above $0^{\circ} \mathrm{C}$ (Monthly Climate Statistics for Syowa Station available at the Japan Meteorological Agency website). During snowmelt events, meltwater percolated downward to the slush layer, suggesting that the decreases in DMS concentrations and salinity of slush water were caused by dilution resulting from the melting of snow and ice. The DMS concentration and salinity of slush water were highly correlated $\left(R^{2}=0.82, p<0.005\right.$; Figure 5$)$, supporting the inference that dilution occurred as a result of the melting of snow and ice.

[19] In under-ice water, DMS concentrations increased from $4.4 \mathrm{nM}$ on 12 January to $9.5 \mathrm{nM}$ on 2 February (Figure $4 \mathrm{c}$ and Table 2). Chlorophyll $a$ concentrations in under-ice water also increased from $0.1 \mu \mathrm{g} \mathrm{L}^{-1}$ on 12 January to $1.0 \mu \mathrm{g}$ $\mathrm{L}^{-1}$ on 2 February (Figure $4 \mathrm{~d}$ and Table 2). Salinity, however, decreased from 33.2 on 12 January to 31.1 on 2 February. Generally, DMS concentrations are much higher at the bottom of sea ice than in under-ice water [e.g., Delille et al., 2007] owing to the high biological productivity of ice algae [Thomas et al., 1995]. Therefore, we inferred that an influx of sea-ice meltwater contributed to the high DMS concentrations in the under-ice water, as discussed by Trevena and Jones [2006]. This mechanism can explain the increase in DMS concentrations and the decrease in salinity in under-ice water during the study period. The increase in chlorophyll $a$ concentrations in under-ice water during the same period (Figure $4 \mathrm{~d}$ and Table 2) may also reflect not only in situ biological productivity but also the flushing out of algae from the sea ice along with the meltwater. Although we do not have direct evidence for these processes, they both may have contributed to the changes in the DMS concentrations in the under-ice water.

[20] At the ice-crack station, the maximum DMS concentration, $103.7 \mathrm{nM}$, was found in slush water (Table 2). The maximum chlorophyll $a$ value, $2.7 \mu \mathrm{g} \mathrm{L}^{-1}$, was also found 

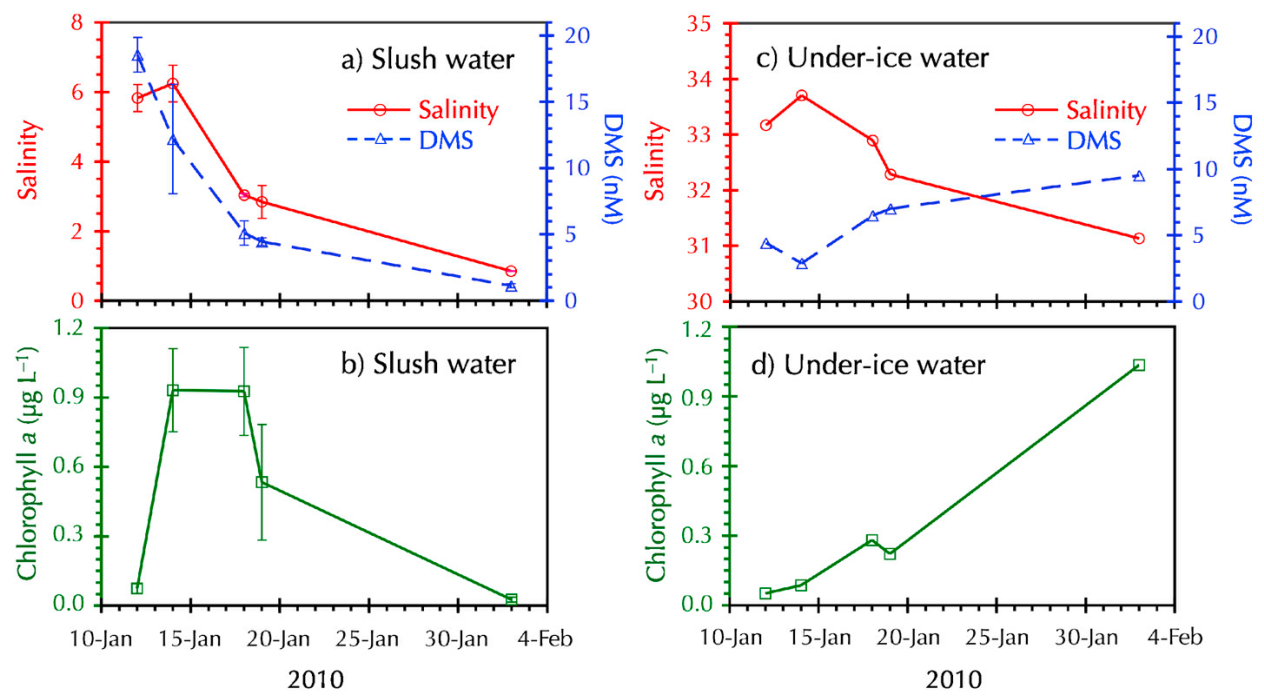

Figure 4. Temporal variations in (a) salinity and the DMS concentration in slush water and (b) the chlorophyll $a$ concentration in slush water at the time series station. Each symbol with an error bar indicates the mean value obtained from duplicate measurements within a $2 \mathrm{~m}^{2}$ area. In Figures $4 \mathrm{a}$ and $4 \mathrm{~b}$ error bars indicate the maximum and minimum values of the duplicate measurements. Temporal variations in (c) salinity and DMS concentration in under-ice water, and in (d) chlorophyll $a$ concentration in under-ice water, at the time series station.

in slush water at this site (Table 2). The slush layer had a brown color, which is often associated with high biological activity. Therefore, the maximum DMS value most likely reflects high productivity. At the melt pond station, salinity (0.1), the DMS concentration $(<3.7 \mathrm{nM})$, and the chlorophyll $a$ concentration $\left(0.02 \mu \mathrm{g} \mathrm{L}^{-1}\right)$ in the melt pond water were all low (Table 2).

\subsection{Observed DMS Flux}

[21] The DMS fluxes directly measured over the slush layer $\left(\mathrm{F}_{\text {slush }}\right)$ ranged from 0.1 to $5.3 \mu \mathrm{mol} \mathrm{m}^{-2} \mathrm{~d}^{-1}$ (Table 2). The highest value was obtained at the ice-crack station, where DMS concentrations were highest in the slush water throughout our observation period (see section 3.1 and Table 2). The DMS fluxes measured over the snow and superimposed ice $\left(\mathrm{F}_{\mathrm{s} / \mathrm{s}}\right)$, ranged from 0.1 to $0.3 \mu \mathrm{mol} \mathrm{m}{ }^{-2}$ $\mathrm{d}^{-1}$, were small compared to $\mathrm{F}_{\text {slush }}$ (Table 2). Previous studies have shown that snow accumulation and superimposed ice formation over sea ice effectively impedes the gas exchange of $\mathrm{CO}_{2}$ [Delille, 2006; Nomura et al., 2010a]. Therefore, the difference in $\mathrm{F}_{\text {slush }}$ and $\mathrm{F}_{\mathrm{s} / \mathrm{s}}$ clearly demonstrates that the snow and superimposed ice regulated DMS emissions from the slush layer. The snow and superimposed ice had extremely low salinity $(<0.1)$ and chlorophyll $a$ concentrations $\left(<0.02 \mu \mathrm{g} \mathrm{L}^{-1}\right)$ at the time series station, suggesting that the production of DMS was low in the fresh snow and superimposed ice because of low biological productivity during the period.

[22] The $\mathrm{F}_{\text {slush }}$ (including the measurement over the melt pond with pond ice removal) were highly correlated with DMS concentrations in slush and melt pond water while $F_{s / s}$ were not (Figure 6), suggesting that the differences in DMS concentration between the slush (melt pond) water and the atmosphere were driving $\mathrm{F}_{\text {slush }}$. At the time series station, mean $\mathrm{F}_{\text {slush }}$ decreased from $0.8 \mu \mathrm{mol} \mathrm{m} \mathrm{m}^{-2}$ on 12 January to $0.1 \mu \mathrm{mol} \mathrm{m}^{-2} \mathrm{~d}^{-1}$ on 2 February (Figure $7 \mathrm{a}$ and Table 2), following the variations of DMS concentrations in slush water (Figures $4 \mathrm{a}$ and 6 and Table 2). $\mathrm{F}_{\text {slush was highly }}$ correlated with DMS concentrations in the slush water, and with slush water salinity $\left(R^{2}=0.81, p<0.05\right.$ for DMS concentration, and $R^{2}=0.99, p<0.001$ for salinity), at the time series station. In contrast to $\mathrm{F}_{\text {slush }}, \mathrm{F}_{\mathrm{s} / \mathrm{s}}$ was constant at $0.09 \pm 0.02 \mu \mathrm{mol} \mathrm{m}{ }^{-2} \mathrm{~d}^{-1}$, and small compared to $F_{\text {slush }}$

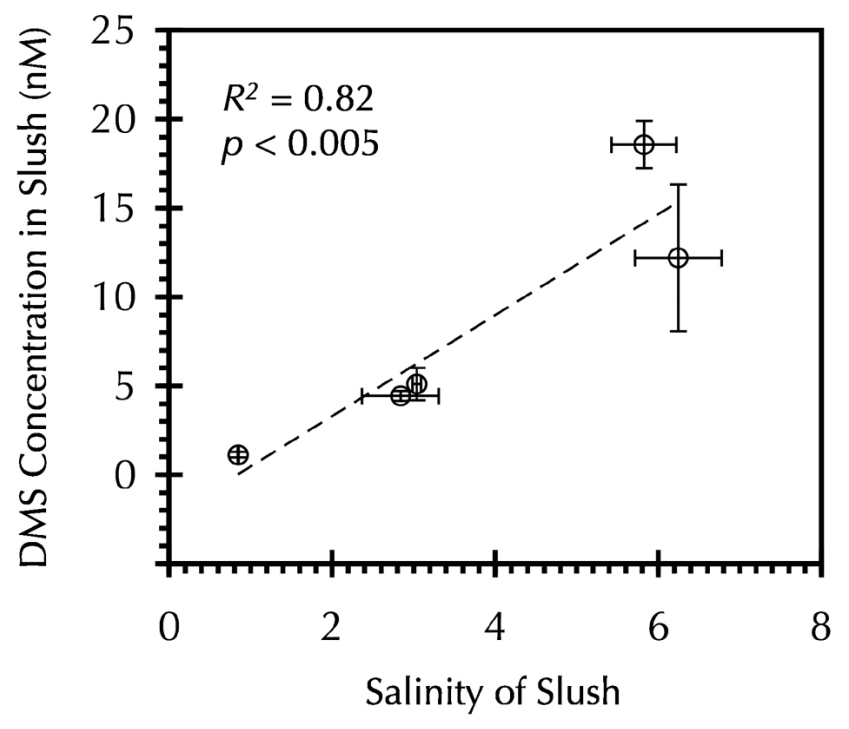

Figure 5. Relationship between the DMS concentration in slush water and slush water salinity at the time series station. Symbols with error bars indicate mean values obtained from duplicate measurements within a $2 \mathrm{~m}^{2}$ area. Error bars indicate the maximum and minimum values of the duplicate measurements. 


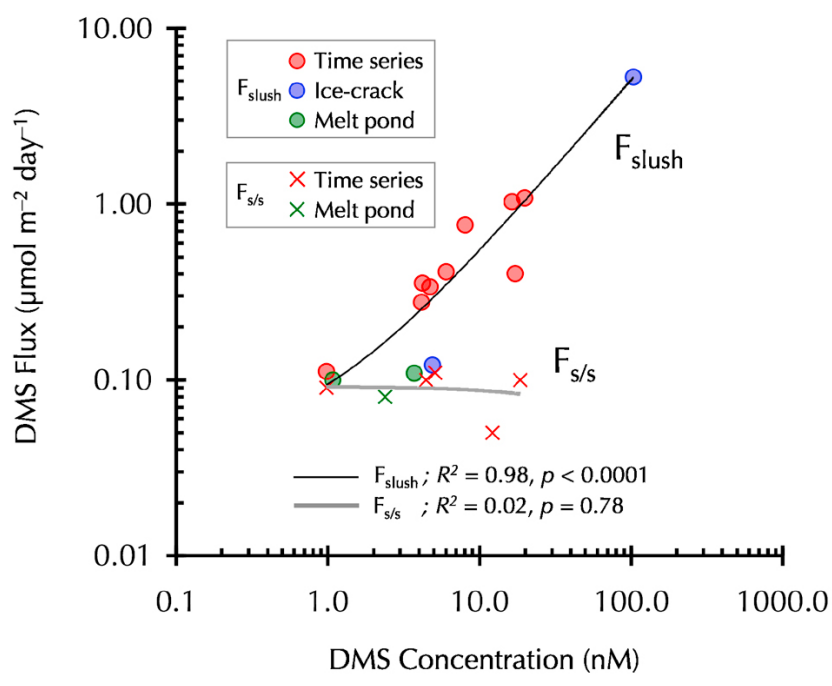

Figure 6. Relationship between DMS concentrations in slush and melt pond water and DMS fluxes measured over the slush $\left(\mathrm{F}_{\text {slush }}\right)$ and the snow and superimposed ice $\left(\mathrm{F}_{\mathrm{s} / \mathrm{s}}\right)$ at the melt pond, ice-crack, and time series stations. For $\mathrm{F}_{\mathrm{s} / \mathrm{s}}$ versus DMS concentrations, mean DMS concentrations for duplicate measurements were used (excluding the ice-crack station data because DMS concentrations varied widely; see Table 2).

(Figure 7a and Table 2). It seems reasonable to infer that $\mathrm{F}_{\text {slush }}$ strongly depend on the DMS concentration in the slush water, although snow cover and the formation of superimposed ice impede gas emissions from sea ice to the atmosphere. We calculated a reduction factor (RF) using the following equation:

$$
R F=1-\left(F_{s / s} / F_{\text {slush }}\right) .
$$

During the observation period, RF decreased from 0.8 on 12 January to 0.2 on 2 February (Figure $7 \mathrm{~b}$ ). The temporal variations of $\mathrm{F}_{\mathrm{s} / \mathrm{s}}$ were constant compared to $\mathrm{F}_{\text {slush }}$ (Figure 7a), indicating that the decrease in RF mainly occurred due to the temporal decreases in $\mathrm{F}_{\text {slush. }}$. Therefore, it is suggested that the decrease in RF was not related to the thickness of the snow and superimposed ice although the thickness of the snow and superimposed ice decreased with decreasing $\mathrm{F}_{\text {slush }}$ (Figures $7 \mathrm{a}$ and $7 \mathrm{~b}$ and Tables 1 and 2 ). At the time series station, $F_{\text {slush }}$ decreased (Figure 7a), following the decrease of DMS concentrations in slush water (Figure 4a). The decrease in DMS concentrations in slush water was caused by dilution resulting from the melting of snow and ice, reflecting the decrease in thickness of the snow and superimposed ice (Figure 7b). Because the decrease in DMS concentrations directly influences the decease in $\mathrm{F}_{\text {slush }}$, it is suggested that the variations of $F_{\text {slush }}$ were not directly related to the thickness of snow and superimposed ice.

\subsection{Comparison With Other Results}

[23] A surface slush (gap) layer is widely found in Antarctic sea ice during the ice melting season [Haas et al., 2001; Kattner et al., 2004; Ackley et al., 2008; Zemmelink et al., 2008; Papadimitriou et al., 2009]. Snow accumulation over sea ice and the formation of superimposed ice leads to the formation of a slush layer below sea level [Haas et al., 2001]. High biological activity in this layer [Kattner et al., 2004] leads to a steep DMS concentration gradient between the slush water and the atmosphere, as reported here. In addition, DMS produced in the slush layer tends to accumulate because of limited diffusion through the snow and superimposed ice. Hence, the slush layer has the potential to emit DMS to the atmosphere when the snow and superimposed ice melts although the removal process of DMS by photolysis reaction [e.g., Toole et al., 2003] can modify the DMS flux from the slush layer. It is important to note that the formation of the slush layer likely occurs frequently in melting Antarctic sea ice [Haas et al., 2001]. However, as long as snow and superimposed ice are present, there is no significant DMS emission to the atmosphere.

[24] Zemmelink et al. [2008] measured extremely high DMS fluxes, with a mean of $11 \mu \mathrm{mol} \mathrm{m} \mathrm{m}^{-2} \mathrm{~d}^{-1}$, by the REA method over biologically productive brown slush. Although their measured DMS concentrations in the slush layer $(<1$ to $92 \mathrm{nM})$ are similar to those obtained in the present study (see section 3.1), there is a discrepancy in DMS flux measurements between their study and ours $\left(0.1\right.$ to $0.3 \mu \mathrm{mol} \mathrm{m} \mathrm{m}^{-2} \mathrm{~d}^{-1}$ for $\mathrm{F}_{\mathrm{s} / \mathrm{s}}$ and 0.1 to $5.3 \mu \mathrm{mol} \mathrm{m} \mathrm{m}^{-2} \mathrm{~d}^{-1}$ for $\left.\mathrm{F}_{\text {slush }}\right)$. $\mathrm{F}_{\mathrm{s} / \mathrm{s}}$ are the environmental fluxes (snow and superimposed ice are part of the natural system). Therefore, for comparison of the environmental fluxes, $\mathrm{F}_{\mathrm{s} / \mathrm{s}}$ obtained in our study $\left(0.1\right.$ to $\left.0.3 \mu \mathrm{mol} \mathrm{m} \mathrm{m}^{-2} \mathrm{~d}^{-1}\right)$ were much smaller than those obtained by Zemmelink et al.

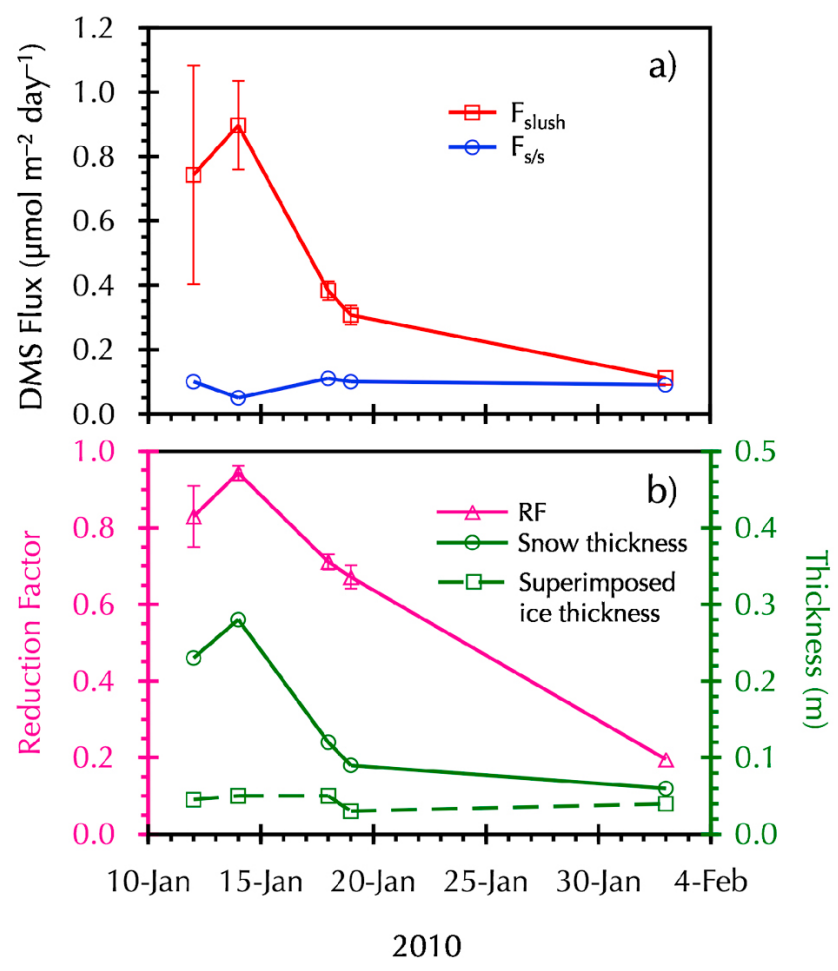

Figure 7. Temporal variations in (a) DMS flux over the snow and superimposed ice $\left(\mathrm{F}_{\mathrm{s} / \mathrm{s}}\right)$ and over the slush layer $\left(\mathrm{F}_{\text {slush }}\right)$ and (b) a reduction factor (RF) and thickness of snow and superimposed ice at the time series station. Symbols with error bars indicate mean values obtained from duplicate measurements within a $2 \mathrm{~m}^{2}$ area. Error bars indicate the maximum and minimum values of duplicate measurements. 
[2008] $\left(11 \mu \mathrm{mol} \mathrm{m} \mathrm{m}^{-2} \mathrm{~d}^{-1}\right)$. It is reasonable to suppose that the one reason for the discrepancy in environmental fluxes was the limitation of the DMS emission through the snow and superimposed ice shown in this study.

[25] The REA and chamber methods measure fluxes on very different spatial scales. The REA method reflects the average flux over a large area [Zemmelink et al., 2008], and it is therefore most useful for understanding large-scale fluxes. It is difficult to distinguish the contribution from different surface types and local events (e.g., a sudden drop in the DMS concentration in the snow) occurring near the REA station [Zemmelink et al., 2008]. Although the chamber method is useful for understanding the relationship between DMS fluxes and ice-surface conditions on small scales, as shown in this study, the spatial scale of this method is limited. Therefore, the different spatial scales of the two methods may be an additional reason for the discrepancy in DMS flux measurements. In addition, the estimation of gas fluxes using chamber methods can be effected by many factors that are not easy to evaluate as shown below.

[26] Because there is no earlier work involving DMS flux measurements, we discuss work involving $\mathrm{CO}_{2}$. The $\mathrm{CO}_{2}$ flux is influenced by wind-driven variations in atmospheric pressure [Winston et al., 1995; Luo and Zhou, 2006; Takagi et al., 2005]. As a result, $\mathrm{CO}_{2}$ fluxes through snow overlying soil [Takagi et al., 2005] or sea ice [Papakyriakou and Miller, 2011] are increased when the wind velocity is high. Furthermore, the buffering effect of snow can allow $\mathrm{CO}_{2}$ to build up in the snowpack before outgassing occurs [Takagi et al., 2005; Zemmelink et al., 2006]. When the flux chamber is placed over the snow, this excess $\mathrm{CO}_{2}$ may be released into the chamber, particularly if a fan is used. In addition, changes in the $\mathrm{CO}_{2}$ concentration within the chamber can suppress the actual $\mathrm{CO}_{2}$ flux with respect to the ambient $\mathrm{CO}_{2}$ concentration [Winston et al., 1995].

[27] To overcome these limitations, in our DMS flux measurements using the chamber technique, we took the following three precautions. (1) Before sampling, we slowly pumped the piston of the glass syringe to homogenize the air within the chamber. (2) We collected samples only on days when wind speeds were low (Monthly Climate Statistics for Syowa Station are available at the Japan Meteorological Agency website) so that the wind-driven turbulent flux would be small, thus minimizing its effects on the derived DMS fluxes. (3) We used a chamber with a large volume to minimize the effect of temporal variations in DMS concentrations. Variations in the DMS concentration in the chamber changed linearly over time during the $40 \mathrm{~min}$ sampling interval (Figure 3), indicating that the gradient between the DMS concentration within of chamber and the ambient concentration was maintained during the experiment. Alteration of the gas concentration gradient directly influences the gas flux from a surface [Hanson et al., 1993]. In that case, the temporal variation of the DMS concentration in the chamber would indicate a saturation curve because the DMS concentration in the chamber would approach equilibrium with that in the slush water. Therefore, the linear relationship of the flux with time shown in Figure 3 supports our inference that this chamber was suitable for use.

[28] In the chamber method, gas fluxes are determined by linear regression of gas concentration measurements against time. The chamber method, in particular the closed-chamber method used in this study, is the most widely used method for measuring gas fluxes over land [e.g., Luo and Zhou, 2006], and it is often applied to gas flux measurement through snow over land [Mariko et al., 1994; Winston et al., 1995; Schindlbacher et al., 2007] or sea ice [Delille, 2006; Nomura et al., 2010a, 2010b], or at the air-sea interface [Frankignoulle, 1988; Tokoro et al., 2007]. Sea ice is a very heterogeneous medium, and it is important to understand how various ice-surface conditions affect the DMS flux. Therefore, in this study we used the chamber method to investigate in detail the relationships between various sea ice surface condition (snow, superimposed ice, melt pond and slush) and the DMS flux values.

[29] The results presented here, as well as the findings of Zemmelink et al. [2008], suggest that the amount of DMS emitted from the sea-ice surface may be an important fraction of the total sulfur budget of the global ocean. However, few data are available for evaluating variations in this flux. Observations are biased by the small areal extent of multiyear ice in the Southern Ocean [Comiso, 2010] and because the measurements have been obtained only in the summer season. Therefore, further investigations are needed for the firstyear sea ice and different seasons in the Southern Ocean. However, the formation of the slush layer observed during the DMS flux measurements in our study and Zemmelink et al. [2008] likely occurs frequently for the wide area in Antarctic sea ice [Haas et al., 2001]. These results suggested that the emission of DMS from the slush layer may be an important fraction of the total sulfur budget of the global ocean when the snow and superimposed ice melt.

[30] High DMS concentrations in leads [Zemmelink et al., 2005] and near the ice crack observed in this study (see section 3.1 and Table 2) suggest additional emission of DMS from the sea-ice zone. In both hemispheres, both spring blooms in open water [del Valle et al., 2009] and the melting of ice with high DMS concentrations would enhance DMS concentrations in surface water, which could potentially lead to an increase in DMS emissions to the atmosphere [Levasseur et al., 1994; Trevena and Jones, 2006]. For these reasons, DMS emissions from melting sea ice and from leads and cracks in the ice are likely very important to the global DMS budget. To understand DMS cycles in ice-covered seas in more detail, however, further investigation of large-scale spatial and temporal processes are needed.

\section{Summary}

[31] We have presented the first measurements of DMS fluxes by the chamber technique from the sea-ice to the atmosphere. A slush layer develops over the surface of Antarctic sea ice under general seasonal warming conditions. We measured $\mathrm{F}_{\text {slush }}$ ranging from 0.1 to $5.3 \mu \mathrm{mol} \mathrm{m} \mathrm{m}^{-2} \mathrm{~d}^{-1}$ during low-wind conditions, to minimize the effect of wind on the flux. We found that the flux was dependent on the DMS concentration in the slush layer, which ranged from 1.0 to $103.7 \mathrm{nM} . \mathrm{F}_{\mathrm{s} / \mathrm{s}}$ were small $\left(0.1\right.$ to $\left.0.3 \mu \mathrm{mol} \mathrm{m} \mathrm{m}^{-2} \mathrm{~d}^{-1}\right)$ compared to the potential fluxes of $\mathrm{F}_{\text {slush }}$, indicating that snow accumulation and the formation of superimposed ice over the slush layer significantly blocked gas exchange through the sea ice. The present results indicate that DMS is both produced and accumulated in the sea-ice slush layer, and slush layer has a 
potential to release the DMS to the atmosphere and ocean when the snow and superimposed ice were melted.

[32] Acknowledgments. We would like to express heartfelt thanks to Y. Motoyoshi, S. Kudoh, S. A. Chavanich, H. Shimoda, the crew of Japan Maritime Shelf-Defense Force icebreaker Shirase, and all the members of JARE-50 and -51 for their support in conducting the field work. We thank M. A. Granskog, N. Sato, T. Odate, H. Y. Inoue, S. Ushio, G. Hashida, K. Takahashi, and T. Iida for their useful comments. We also thank L. A Miller and three anonymous reviewers for their useful comments for our manuscript. This work was partly supported by the Japan Society for the Promotion of Science (21810036) and the National Institute of Polar Research.

\section{References}

Ackley, S. F., M. J. Lewis, C. H. Fritsen, and H. Xie (2008), Internal melting in Antarctic sea ice: Development of "gap layers," Geophys. Res. Lett., 35, L11503, doi:10.1029/2008GL033644.

Comiso, J. C. (2010), Variability and trends of the global sea ice cover, in Sea Ice, 2nd ed., edited by D. N. Thomas and G. S. Dieckmann, pp. 205-246, Wiley-Blackwell, Oxford, U. K

Dacey, J. W. H., S. G. Wakeham, and B. L. Howes (1984), Henry's law constants for dimethylsulfide in freshwater and seawater, Geophys. Res Lett., 11, 991-994, doi:10.1029/GL011i010p00991.

Delille, B. (2006), Inorganic carbon dynamics and air-ice-sea $\mathrm{CO}_{2}$ fluxes in the open and coastal waters of the Southern Ocean, $\mathrm{PhD}$ thesis, Univ. of Liège, Liège, Belgium

Delille, B., B. Jourdain, A. V. Borges, J.-L. Tison, and D. Delille (2007), Biogas $\left(\mathrm{CO}_{2}, \mathrm{O}_{2}\right.$, dimethylsulfide) dynamics in spring Antarctic fas ice, Limnol. Oceanogr., 52, 1367-1379, doi:10.4319/10.2007.52.4.1367. del Valle, D. A., D. J. Kieber, D. A. Toole, J. Brinkley, and R. P. Kiene (2009), Biological consumption of dimethylsulfide (DMS) and its importance in DMS dynamics in the Ross Sea, Antarctica, Limnol. Oceanogr., 54, 785-798, doi:10.4319/lo.2009.54.3.0785

Frankignoulle, M. (1988), Field measurements of air-sea $\mathrm{CO}_{2}$ exchange, Limnol. Oceanogr., 33(3), 313-322, doi:10.4319/lo.1988.33.3.0313.

Haas, C., D. N. Thomas, and J. Bareiss (2001), Surface properties and processes of perennial Antarctic sea ice in summer, J. Glaciol., 47(159), 613-625, doi:10.3189/172756501781831864.

Hanson, P. J., S. D. Wullschleger, S. A. Bohlman, and D. E. Todd (1993), Seasonal and topographic patterns of forest floor $\mathrm{CO}_{2}$ efflux from an upland oak forest, Tree Physiol., 13, 1-15.

Kameyama, S., H. Tanimoto, S. Inomata, U. Tsunogai, A. Ooki, Y. Yokouchi, S. Takeda, H. Obata, and M. Uematsu (2009), Equilibrator inlet-proton transfer reaction-mass spectrometry (EI-PTR-MS) for sensitive, highresolution measurement of dimethyl sulfide dissolved in seawater, Anal. Chem., 81, 9021-9026, doi:10.1021/ac901630h.

Kattner, G., D. N. Thomas, C. Haas, H. Kennedy, and G. S. Dieckmann (2004), Surface ice and gap layers in Antarctic sea ice: Highly productive habitats, Mar. Ecol. Prog. Ser., 277, 1-12, doi:10.3354/meps277001

Levasseur, M. M. Gosselin, and S. Michaud (1994), A new source of dimethylsulfide (DMS) for the Arctic atmosphere: Ice diatoms, Mar. Biol. Berlin, 121, 381-387, doi:10.1007/BF00346748.

Liss, P. S., A. D. Hatton, G. Malin, P. D. Nightingale, and S. M. Turner (1997), Marine sulphur emissions, Philos. Trans. R. Soc. London B, 352, 159-169, doi:10.1098/rstb.1997.0011

Loose, B., P. Schlosser, P. Perovich, D. Ringelberg, D. T. Ho, T. Takahashi, J. Richter-Menge, C. M. Reynolds, W. R. McGillis, and J.-L. Tison (2011), Gas diffusion through columnar laboratory sea ice: Implications for mixed-layer ventilation of $\mathrm{CO}_{2}$ in the seasonal ice zone, Tellus, Ser. $B, 63,23-39$, doi:10.1111/j.1600-0889.2010.00506.x

Luo, Y., and X. Zhou (2006), Soil Respiration and the Environment, Elsevier, London.

Mariko, S., Y. Bekku, and H. Koizumi (1994), Efflux of carbon dioxide from snow-covered forest floors, Ecol. Res., 9(3), 343-350, doi:10.1007/ BF02348421.

Mikkelsen, D. M., and A. Witkowski (2010), Melting sea ice for taxonomic analysis: A comparison of four melting procedures, Polar Res., 29 , 451-454, doi:10.1111/j.1751-8369.2010.00162.x.

Miller, L. A., T. N. Papakyriakou, R. E. Collins, J. W. Deming, J. K. Ehn, R. W Macdonald, A. Mucci, O. Owens, M. Raudsepp, and N. Sutherland (2011), Carbon dynamics in sea ice: A winter flux time series, J. Geophys. Res., 116, C02028, doi:10.1029/2009JC006058.

Nomura, D., H. Yoshikawa-Inoue, and T. Toyota (2006), The effect of seaice growth on air-sea $\mathrm{CO}_{2}$ flux in a tank experiment, Tellus, Ser. B, 58 , 418-426, doi:10.1111/j.1600-0889.2006.00204.x.
Nomura, D., H. Yoshikawa-Inoue, T. Toyota, and K. Shirasawa (2010a), Effects of snow, snowmelting and refreezing processes on air-sea-ice $\mathrm{CO}_{2}$ flux, J. Glaciol., 56(196), 262-270, doi:10.3189/002214310791968548. Nomura, D., H. Eicken, R. Gradinger, and K. Shirasawa (2010b), Rapid physically driven inversion of the air-sea ice $\mathrm{CO}_{2}$ flux in the seasonal landfast ice off Barrow, Alaska after onset of surface melt, Cont. Shelf Res., 30, 1998-2004, doi:10.1016/j.csr.2010.09.014.

Papadimitriou, S., D. N. Thomas, H. Kennedy, H. Kuosa, and G. S. Dieckmann (2009), Inorganic carbon removal and isotopic enrichment in Antarctic sea ice gap layers during early austral summer, Mar. Ecol. Prog. Ser., 386, 15-27, doi:10.3354/meps08049.

Papakyriakou, T., and L. Miller (2011), Springtime $\mathrm{CO}_{2}$ exchange over seasonal sea ice in the Canadian Arctic Archipelago, Ann. Glaciol., 52(57), 215-224, doi:10.3189/172756411795931534

Parsons, T. R., M. Takahashi, and B. Hargrave (1984), Biological Oceanographic Processes, 3rd ed., 330 pp., Pergamon, Oxford, U. K. Schindlbacher, A., S. Zechmeister-Boltenstern, G. Glatzel, and R. Jand (2007), Winter soil respiration from an Austrian mountain forest, Agric. For. Meteorol., 146, 205-215, doi:10.1016/j.agrformet.2007.06.001.

Semiletov, I., A. Makshtas, S.-I. Akasofu, and E. L. Andreas (2004), Atmospheric $\mathrm{CO}_{2}$ balance: The role of Arctic sea ice, Geophys. Res. Lett., 31, L05121, doi:10.1029/2003GL017996.

Suzuki, R., and T. Ishimaru (1990), An improved method for the determination of phytoplankton chlorophyll using $\mathrm{N}$, N-dimethylformamide, J. Oceanogr. Soc. Jpn., 46, 190-194, doi:10.1007/BF02125580.

Takagi, K., M. Nomura, D. Ashiya, H. Takahashi, K. Sasa, Y. Fujinuma, H. Shibata, Y. Akibayashi, and T. Koike (2005), Dynamic carbon dioxide exchange through snowpack by wind-driven mass transfer in a coniferbroadleaf mixed forest in northernmost Japan, Global Biogeochem. Cycles, 19, GB2012, doi:10.1029/2004GB002272.

Thomas, D. N., R. J. Lara, H. Eicken, G. Kattner, and A. Skoog (1995), Dissolved organic matter in Arctic multi-year sea ice during winter: Major components and relationship to ice characteristics, Polar Biol., 15, 477-483, doi:10.1007/BF00237461.

Tokoro, T., A. Watanabe, H. Kayanne, K. Nadaoka, H. Tamura, K. Nozaki, K. Kato, and A. Negishi (2007), Measurement of air-water $\mathrm{CO}_{2}$ transfer at four coastal sites using a chamber method, J. Mar. Syst., 66 140-149, doi:10.1016/j.jmarsys.2006.04.010.

Toole, D. A., D. J. Kieber, R. P. Kiene, D. A. Siegel, and N. B. Nelson (2003), Photolysis and the dimethylsulfide (DMS) summer paradox in the Sargasso Sea, Limnol. Oceanogr., 48, 1088-1100, doi:10.4319/ 1o.2003.48.3.1088.

Trevena, A. J., and G. B. Jones (2006), Dimethylsulphide and dimethylsulphoniopropionate in Antarctic sea ice and their release during sea ice melting, Mar. Chem., 98, 210-222, doi:10.1016/j.marchem. 2005.09.005

Winston, G. C., B. B. Stephens, E. T. Sundquist, J. P. Hardy, and R. E. Davis (1995), Seasonal variability in $\mathrm{CO}_{2}$ transport though snow in a boreal forest, in Biogeochemistry of Seasonally Snow-Covered Catchments, edited by K. A. Tonnessen, M. W. Williams, and M. Tranter, IAHS Publ., 228, 61-70.

Zemmelink, H. J., L. Houghton, J. W. H. Dacey, A. P. Worby, and P. S. Liss (2005), Emission of dimethylsulfide from Weddell Sea leads, Geophys. Res. Lett., 32, L23610, doi:10.1029/2005GL024242.

Zemmelink, H. J., B. Delille, J. L. Tison, E. J. Hintsa, L. Houghton, and J. W. H. Dacey (2006), $\mathrm{CO}_{2}$ deposition over the multi-year ice of the western Weddell Sea, Geophys. Res. Lett., 33, L13606, doi:10.1029/ 2006GL026320.

Zemmelink, H. J., J. W. H. Dacey, L. Houghton, E. J. Hintsa, and P. S. Liss (2008), Dimethylsulfide emissions over the multi-year ice of the western Weddell Sea, Geophys. Res. Lett., 35, L06603, doi:10.1029/ 2007GL031847.

M. Fukuchi and M. Wada, National Institute of Polar Research, 10-3 Midori-cho, Tachikawa-shi, Tokyo 190-8501, Japan.

N. Kasamatsu, Graduate School of Marine Science and Technology, Tokyo University of Marine Science and Technology, 4-5-7 Konan, Minato-ku, Tokyo 108-8477, Japan.

S. Koga, Research Institute for Environment Technology, National Institute of Advanced Industrial Science and Technology, AIST Tsukuba West, 16-1 Onogawa, Tsukuba, Ibaraki 305-8569, Japan.

D. Nomura, Norwegian Polar Institute, Fram Centre, N-9296 Tromsø, Norway. (daiki.nomura@npolar.no)

H. Shinagawa, Shimoda Marine Research Center, University of Tsukuba, 5-10-1 Shimoda, Shizuoka 415-0025, Japan.

D. Simizu, Institute of Low Temperature Science, Hokkaido University, Kita-19, Nishi-8, Kita-ku, Sapporo, Hokkaido 060-0819, Japan. 